\title{
ANALISIS PSIKOLIGIS NOVEL NEGERI 5 MENARA KARYA AHMAD FUADI
}

\author{
Abdul Aziz \\ Mahasiswa Program Pascasarjana Bahasa dan Sastra Indonesia Universitas Negeri Padang \\ abdaazizo8@gmail.com
}

\begin{abstract}
Abstrak
Sastra merupakan gambaran hasil rekaan seseorang dan menghasilkan kehidupan yang diwarnai oleh sikap. Dengan demikian karya sastra dapat di dekati dengan menggunakan pendekatan psikologis. Masalah penelitian ini tentang psikologis yang terkandung dalam novel Negeri Lima Menara Karya Ahmad Fuadi. Penelitian ini bertujuan untuk mengetahui deskripsi gambaran psikologis tokoh Alif dari Novel Negeri Lima Menara karya Ahmad Fuadi yang berjumlah 425 halaman. Penerbit PT Gramedia Pustaka Utama, Jakarta. 2009. Data penelitian ini adalah gambaran psikologis tokoh Alif. Metode yang digunakan adalah metode deskriptif dengan analisis kualitatif dengan mendeskripsikan gambaran psikologis tokoh Alif dalam Novel Negeri Lima Menara Karya Ahmad Fuadi dengan Pendekatan Psikologis. Metode ini didasarkan atas pertimbangan akan adanya kesesuaian antara bentuk penelitian dan tujuan penelitian. Instrument penelitian dilakukan dengan studi dokumentasi. Studi dokumentasi dilakukan terhadap Novel Negeri Lima Menara Karya Ahmad Fuadi dengan Pendekatan Psikologis. Dari hasil penelitian ini dapat diperoleh informasi bahwa gambaran tokoh Alif yaitu, pemarah, pencemas, penakut, depresi, ragu dan bimbang.
\end{abstract}

\section{Kata kunci :}

\section{PENDAHULUAN}

Padazamanmodernsekarangini,sastradianggap semakin penting. Bukan saja sastra diciptakan namun terus diapresiasikan masyarakat untuk memperhalus budi dan memperkaya spiritual serta hiburan dan juga telah masuk dalam kurikulum sekolah sebagai pengetahuan budaya. Penguasaan teori merupakan salah satu cara dalam memahami karya sastra, dapat dipertanggungjawabkan secara ilmiah, meskipun sastra itu sendiri bersifat penafsiran. Untuk itu mahasiswa jurusan bahasa dan sastra Indonesia yang notabenenya bergelut di dunia sastra perlu memahami dan menguasai ilmu sastra, dan melalui kegiatan-kegiatan yang lainnya menyangkut tentang sastra.

Karya sastra, sebagai sebuah struktur terdiri atas unsur yang tersusun secara bersistem. Membicarakan sastra yang bersifat imajinatif, berhadapan dengan tiga jenis genre sastra, yaitu prosa, puisi dan drama. Prosa dalam pengertian kesastraan juga disebut fiksi, teks naratif, atau wacana naratif. Istilah fiksi dalam pengertian ini adalah cerita rekaan atau cerita khayalan. Hal itu disebabkan karena fiksi merupakan karya naratif yang isinya tidak menyaran pada kebenaran sejarah sebagai sebuah karya imajiner, fiksi menawarkan berbagai permasalahan manusia dan kemanusiaan, hidup dan kehidupan. Salah satu jenis prosa adalah novel, merupakan bagian dari karya fiksi yang memuat pengalaman manusia secara menyeluruh atau merupakan suatu terjemahan tentang perjalanan hidup yang bersentuhan dengan kehidupan manusia, sehingga dapat dikatakan bahwa karya fiksi berupa novel adalah suatu potret realitas yang terwujud melalui bahasa yang estetis.

Penelitian yang menggunakan pendekatan psikologis terhadap karya sastra merupakan bentuk pemahaman dan penafsiran karya sastra 
dari sisi psikologi. Alasan ini didorong karena tokoh-tokoh dalam karya sastra dimanusiakan, mereka semua diberi jiwa, mempunyai raga bahkan untuk manusia yang disebut pengarang mungkin memiliki penjiwaan yang lebih bila dibandingkan dengan manusia lainnya. Terutama dalam hal penghayatan mengenai hidup dan kehidupan.

Identifikasi dalam penelitian ini adalah uraian faktor yang mendorong peneliti untuk mengadakan penelitian mengenai analisis psikologis. Tokoh novel Negeri 5 Menara karya Ahmad Fuadi. Kejelasan identifikasi masalah sangat diperlukan sebagai pedoman bagi peneliti untuk kemudahan proses pengujian,menghindari kemungkinankemungkinan terjadinya penyimpangan dalam pembahasan masalah.

Mengingat keterbatasan dari kemampuan yang peneliti miliki, untuk menghindari kesimpang siuran dalam pembahasan dan penganalisisan maka penelitian dibatasi pada analisis gambaran psikologi tokoh Alif. Permasalahan sebagai dasar penulisan, maka berdasarkan identifikasi dan pembatasan masalah di dalam skripsi ini adalah bagaimana deskripsi psikologis tokoh Alif dalam novel Negeri 5 Menara karya Ahmad Fuadi.

Setiap penelitian harus memiliki tujuan yang jelas karena dengan tujuan yang jelas akan memudahkan peneliti atau pembaca untuk meneliti permasalahan. Berdasarkan rumusan masalah yang dikemukakan di atas, maka secara umum tujuan penelitian ini adalah untuk mendeskripsikan psikologis tokoh Alif dalam novel Negeri 5 Menara karya Ahmad Fuadi. Penelitian ini bermanfaat secara teoretis maupun praktis, penelitian ini merupakan masukan kepada novel agar dalam penulisan novel lebih mengarah kepada kehidupan sosial yang terjadi saat ini. Secara praktis, penelitian ini bermanfaat yang diharapkan dari penelitian ini. Sebagai bahan masukan dan pengetahuan bagi guru bidang studi Bahasa dan Sastra Indonesia, khususnya dalam pengkajian sastra.

Dalam penelitian ilmiah kerangka teoretis memuat sejumlah teori yang berkaitan dengan permasalah dalam penelitian. Untuk memperoleh teori haruslah berpedoman pada ilmu peng- etahuan yakni dengan cara belajar, oleh sebab itu, kerangka teoretis merupakan rancangan teori yang berhubungan hakikat suatu penelitian untuk menjelaskan penelitian variabel-variabel yang akan diteliti. Psikologi sastra adalah suatu kajian yang menekankan pada segi-segi psikologis yang terdapat dalam suatu karya sastra hal itu terjadi disebabkan timbulnya kesadaran bagi para pengarang yang dengan sendirinya juga bagi kritikus sastra, bahwa perkembangan dan kemajuan masyarakat modern ini tidaklah semata-mata dapat diukur dari segi material, tetapi juga dari segi rohanian dan kejiwaan. (Semi, 1985:46).

Psikologi sastra merupakan gabungan dari dua disiplin ilmu yang bervariasi yaitu, psikologis dan sastra. Sastra sebagai "gejala kejiwaan" di dalamnya terkandung fenomena-fenomena kejiwaan yang tampak lewat perilaku tokoh-tokohnya, sehingga karya teks sastra dapat dianalisis dengan menggunakan pendekatan psikologi. Antara sastra dengan psikologi memiliki hubungan lintas yang bersifat tak langsung fungsional, menurut Yatman (dalam Minuddin, 1990,93). Pengarang dan psikologi kebetulan memiliki tempat berangkat yang sama' yakni kejiwaan manusia. Keduanya mampu menangkap kejiwaan manusia secara mendalam. Perbedaannya, jika pengarang mengungkapkan temuannya dalam bentuk karya sastra, sedangkan psikologi sesuai keahliannya mengemukakan dalam bentuk formula teoriteori psikologi. Karya sastra yang dapat dijadikan bahan kajian melalui pendekatan secara psikologi adalah karya-karya sastra yang mengembangkan kejiwaan tokoh- tokohnya, yakni karya prosa dan drama. Jadi, psikologi sastra adalah suatu analisis mengenai kejiwaan tokoh-tokoh dalam karya sastra yang menggunakan teori-teori tentang ilmu psikologi.

Kerangka teoretis telah dijelaskan apa yang menjadi pokok permasalahan dalam penelitian ini. Pada kerangka konseptual ini peneliti menyajikan konsep-konsep dasar yang sesuai dengan permasalahan yang akan diteliti. Sastra merupakan karya tulis yang memiliki cirri-ciri keunggulan, seperti keaslian, keindahan isi ungkapan sastra dan sastra itu menyenangkan. Sastra dilahirkan oleh 
dorongan dasar manusia untuk mengungkapkan dirinya, menaruh minat terhadap masalah manusia dan kemanusia yang berlangsung sepanjang zaman. Sesuai dengaan masalah, maka penelitian ini membuat pernyataan sebagai pengganti dari hipotesis. Adapun pernyataan ini adalah terdapat masalah psikologis tokoh Alif dalam Novel Negeri 5 Menara Karya Ahmad Fuadi.

\section{METODE PENELITIAN}

Penelitian ini merupakan studi pustaka dan kegiatan yang dilakukakn dengan mengumpulkan dan menganalisis data penelitian dari Novel Negeri 5 Menara Karya Ahmad Fuadi. Waktu yang dilaksanakan dalam melakukan penelitian ini selama enam bulan yaitu terhitung dari bulan Oktober 2015 sampai dengan bulan Maret 2016. Sumber data penelitian ini adalah tampilan yang berupa fakta- fakta lisan atau tulisan yang dicermati oleh peneliti dan benda-benda yang diamati sampai detalinya agar dapat tertangkap makna yang tersirat dalam dokumen bendanya. Menurut Moleong (dalam Arikunto, 2010;22). Sumber data dari penelitian adalah novel Negeri 5 Menara karya Ahmad Fuadi yang berjumlah 425 halaman. Penerbit PT Gramedia Pustaka Utama, Jakarta 2009. Adapun data penelitian ini adalah gambaran psikologis tokoh Alif, dalam Novel Negeri 5 Menara Karya Ahmad Fuadi dan identitas novel ini adalah, Tema (Manjadda Wajadda), Karya (Ahmad Fuadi), jumlah halaman (425 Halaman), Penerbit (PT Gramedia Pustaka Utama, Jakarta), tahun terbit (2009), cetakan (1).

Metode penelitian adalah cara untuk mengungkapkan atau menganalisis suatu permasalahan yang menjadi objek penelitian. Untuk mencapai tujuan yang telah ditetapkan, penulis memerlukan metode. Metode merupakan cara kerja yang harus ditempuh dalam suatu penelitian ilmiah. Metode yang digunakan dalam penelitian ini adalah melalui metode deskripstif dengan analisis data kualitatif model kajian tekstual dengan pendekatan psikologis. Penelitian deskriptif kualitatif adalah penelitian yang ditujukan untuk mendeskripsikan dan menganalisis objek - objek, peristiwa, aktivitas sosial secara alamiah (Moleong, 2010:11). Penelitian ini berupaya memaparkan suatu peristiwa secara rinci, sistematis, cermat, dan faktual mengenai aspek perkembangan psikologis tokoh Alif, dalam novel Negeri 5 Menara karya Ahmad Fuadi). Instrumen penelitian dilakukan dengan studi dokumentasi. Studi dokumentasi dilakukan dengan menganalisis psikologis tokoh novel Negeri 5 Menara karya Ahmad Fuadi. Penelitian ini dilakukan peninjauan dengan mencatat, memberi tanda pada bagian-bagian baik berupa tokoh maupun tokoh maupun uraian peneliti yang dapat dianggap bermanfaat dan berpengaruh bagi pembaca. Instrumen dalam penelitian yaitu adalah (1) mencari dan menentukan tokoh cerita yang dikaji,(2) menelusuri perkembangan karakter sang tokoh yang dikaji,(3) mengidentifikasi macam-macam perilaku sang tokoh dalam mendeskripsikan,serta mengklasifikasikasinnya (4) mengidentifikasi lingkungan yang telah membentuk perilaku tokoh (5) menghubungkan perilaku yang muncul dengan lingkungan yang melatarinya.

Analisis data merupakan bagian bagian yang amat penting dalam metode ilmiah, karena dengan analisislah data tersebut data diberi arti dan makna yang berguna dalam memecahkan masalah penelitian. Teknik yang digunakan dalam penelitian ini adalah menentukan data. Jadi langkah-langkah yang ditempuh oleh si penulis dalam penelitian. Membaca sastra secara cermat novel Negeri 5 Menara Karya Ahmad Fuadi Peneliti membaca novel yang menjadi objek penelitian, dalam hal ini adalah novel Negeri 5 Menara Karya Ahmad Fuadi. Kegiatan membaca novel dilakukan dengan teknik membaca sekilas dilakukan untuk memahami jalan cerita, pada tahap membaca pemahaman yang bertujuan agar peneliti memahami permasalahan yang terdapat pada novel yang dikaji. Memahami gambaran psikologis tokoh utama Alif dalam novel. Membaca evaluasi tujuannya untuk menyimpulkan novel Negeri 5 Menara karya Ahmad Fuadi. Permasalahan yang terdapat dalam pada novel Negeri 5 Menara karya Ahmad Fuadi. Mengumpulkan data yang berkaitan dengan penelitian. Tahap pengumpulan data.

\section{HASIL PENELITIAN}

Untuk memperoleh data dalam penelitian ini 
peneliti terlebih dahulu membaca secara terperinci novel Negeri 5 Menara karya Ahmad Fuadi, hal ini dilakukan agar peneliti memperoleh pemahaman penokohan dalam novel Negeri 5 Menara karya Ahmad Fuadi dengan pendekatan Psikologis.

Perubahan psikologis dalam novel Negeri 5 Menara karya Ahmad Fuadi dari segi psikologis yang terdapat dalam tokoh Alif. Berikut ini peneliti akan menguraikan tema dalam novel Negeri 5 Menara karya Ahmad Fuadi. Novel Negeri 5 Menara merupakan salah satu karya dari Ahmad Fuadi. Novel ini menceritakan tentang semangat dan perjuangan seorang anak yang bernama Alif dalam meraih masa depan. Banyak yang bisa diambil dari novel ini, kesabaran dan kegigihan dalam menghadapi semua masalah hidupnya. Novel ini sangat menarik dan megharukan tentang perjuangan dan semangat seorang anak yang menuntut ilmu dan membela agama untuk dunia dan akhirat. Awalnya Alif adalah seseorang yang tidak pernah putus asa, namun karena kebimbangan dan ragu yang dihadapinya terlalu berat maka terjadilah konflik batin di dalam diri Alif yang mengakibatkan Alif menjadi pemarah, pencemas, ketakutan, depresi, dan ragu.

- Dalam novel ini dianalisis gambaran psikologis tokoh Alif. Untuk lebih jelasnya dapat dilihat dari analisis data berikut ini. Alif adalah remaja yang baik, namun akibat masalah- masalah yang dihadapinya terjadi konflik batin dalam dirinya. Alif mengalami pemarah, pencemas, ketakutan, depresi, dan ragu. Alif marah ketika berbicara dengan amaknya dalam masalah ilmu agama dan akhirat.

Tapi amak, ambo tidak berbakat dengan ilmu agama. Ambo ingin menjadi insinyur dan ahli ekonomi," tangkisku sengit. Mukaku merah dan mata terasa panas. (Negeri 5 Menara, 2009:9)

- Alif marah dan emosi setelah berbicara dengan Amak dan langsung masuk ke kamarnya.

Aku mengerjap-ngerjap terkejut. Leherku rasanya layu. Kursi rotan tempat dudukku berderit ketika aku menekurkan kepala dalam-dalam. SMA dunia impian yang sudah aku bangun lama di kepalaku pelan-pelan gemeretak, dan runtuh jadi abu dalam sekejap mata.
(Negeri Lima 5, 2009:10)

- Alif kesal dan marah karena membuat keputusan dari Amaknya untuk merantau jauh.

Banyak sekali yang terjadi dalam beberapa hari ini. Hanya enam hari lalu aku kesal dan marah dengan nasib, empat hari lalu aku membuat keputusan ekstrim untuk merantau jauh, tiga hari kemudian aku meninggalkan kampung untuk pertama kalinya menuju tempat yang aku tidak tahu. (Negeri 5 Menara, 2009:37)

- Alif cemas dan curiga dengan Ayah dan Amaknya ketika membicarakan masalah biaya pendaftaran SMA.

Aku curiga, ini pasti soal biaya pendaftaran masuk SMA. Amak dan Ayah mungkin sedang tidak punya uang. Baru beberapa bulan lalu mereka menyicil rumah. (Negeri 5 Menara, 2009:6)

- Alif merasa gelisah karena keputusan untuk merantau ke Jawa.

Sementara bagi aku sendiri, bukan perpisahan yang aku risaukan. Aku gelisah sendiri dengan keputusanku merantau muda ke Jawa. (Negeri 5 Menara, 2009:14)

- Alif merasa gelisah dan bimbang hatinya menjauhi kampung halamannya.

- Tapi semakin jauh bus berlari, semakin gelisah hatiku. Jangan berdetak aneh, menyadari aku sekarang benar-benar meninggalkan kampungku. Bimbang dan ragu hilang timbul. Apakah perjalanan ini keputusan yang paling tepat? Bagaimana kalau aku tidak betah di tempat asing? Bagaimana kalau pondok itu seperti penjara? Bagaimana kalau gambaran Pondok Madani dari Pak Etek Gindo itu salah? Pertanyaan demi pertanyaan bergumpal-gumpal menyumbat kepalaku. (Negeri 5 Menara, 2009:17)

\section{PENUTUP}

Berdasarkan hasil penelitian yang telah dijelaskan dapat ditarik suatu kesimpulan. Hal ini dimaksudkan agar pendapat-pendapat yang telah dikemukakan dalam pembahasan dapat menjadi suatu pendapat yang bersifat umum dan universal.

Alif merupakan tokoh utama dalam novel ini, Tokoh Alif mengalami Kemarahan ketika mendengarkan keputusan Amak tidak masuk 
ke sekolah umum tapi masuk ke sekolah agama mendalamiilmu akhirat. Alif mengalamikecemasan ketika mendengar percakapan Amak dengan Ayah, untuk melepaskan anaknya merantau ke Jawa menuntut ilmu agama. Alif mengalami ketakutan seandainya dia masuk Pondok Pesantren dan tampungan dengan anak-anak bandal dan mentiko. Alif mengalami depresi ketika angan-anganya masuk ke SMA favorit hilang, dan harus mengikuti keputusan Amak untuk masuk sekolah agama.

\section{SARAN}

Berdasarkan yang telah dipaparkan sebagai hasil kesimpulan penelitian ini ada beberapa hal penting yang dapat dikemukakan sebagai saran.

1. Novel Negeri Lima Menara Karya Ahamad Fuadi layak sebagai materi ajar apresiasi sastra di sekolah. Hal ini dapat diaplikasikan untuk kerelaan melakukan yang terbaik untuk sesama.

2. Bagi calon guru, agar lebih meningkatkan dan memperluas pengalaman dan pengetahuannya dengan lebih banyak membaca sekaligus menggali kekayaan yang terkandung dalam karya sastra demi peningkatan kualitas pengajaran khususnya apresiasi sastra.

3. Bagi pembaca hendaknya bisa memetik hikmah yang terdapat dalam cerita dan dapat dijadikan motivasi serta penambahan wawasan mengenai nilai-nilai psikologis yang terdapat dalam cerita tersebut.

\section{DAFTAR PUSTAKA}

Ahmadi, Abu. 1990. Psikologi Sosial. Jakarta: Rineka cipta.

Aminuddin. 1990. Kajian Tekstual dalam Psikologi Sastra. Sekitar Masalah Sastra.. Beberapa Prinsip dan Model Pengembangannya. Malang: Yayasan Asah Asih Asuh Malang.

Arikunto, Suharsimi. 2010. Prosedur Penelitian Suatu Pendekatan Praktik. Jakarta: Rineka cipta.

Departemen Agama RI. (2000). Al-Qur'an dan terjemahannya. Semarang: Toha Putra.

Fuadi, Ahmad. 2009. Negeri 5 Menara. Jakarta: PT Gramedia Pustaka Utama.

Moleong, Lexy J. 1988. Metodologi Penelitian Kualitatif. Bandung: PT Remaja Rosdakarya.

Semi, Atar. 1993. Anatomi Sastra. Bandung: Angkasa Raya.

Semi, Atar. 1985. Kritik Sastra. Bandung: Angkasa. Siswanto, Wahyudi. 2013. Pengantar Teori Sastra. Jakarta: PT Grasindo.

Sugiyono. 2010. Metode Penelitian Pendidikan. Bandung: Alfabeta.

Suryabrata, Sumadi. 2002. Psikologi Kepribadian. Jakarta: Raja Grafindo Persada.

Walgito, Bimo. 1978. Psikologi Sosial : Suatu Pengantar. Yogyakarta: Andi.

(https://id.m.wikipedia.org/wiki/DepresiPsikologi).

(https://id.m.wikipedia.org/wiki/Keraguan dan Kebimbangan-Psikologi. 